\title{
The conservation status of the Wedge- tailed Eagle in Australian law and thoughts on the value of early legal intervention in the conservation of a species
}

\author{
Johann Knobel* \\ $B L C L L D$ \\ Professor of Private Law, University of South Africa
}

\section{OPSOMMING}

Die Bewaringstatus van die Wigstertarend in die Australiese Reg en Gedagtes oor die Waarde van 'n Vroeë Regsingreep Ten Aansien van die Bewaring van 'n Spesie

Die Wigstertarend (Aquila audax) was histories een van die mees vervolgde roofvoëlspesies op aarde. Tans geniet dié arend volledige regsbeskerming. Die Australiese omgewingsreg het waarskynlik 'n belangrike bydraende rol gespeel ten opsigte van die prima facie gunstige bewaringstatus van die spesie. Vergeleke met die intensiewe bewaringsingrepe wat in Spanje ten opsigte van die Spaanse Keiserarend (Aquila adalberti) van regsweë vereis word, is die bewaringsingrepe wat regtens op die Australiese vasteland ten opsigte van die Wigstertarend vereis word, veel meer beperk in aantal, reikwydte en intensiteit. Die Australiese bewaringsingrepe kan egter prima facie as effektief beskou word, en kan waarskynlik onder andere toegeskryf word aan die feit dat volledige regsbeskerming ingetree het voordat die spesie deur uitwissing bedreig is. Daar word aan die hand gedoen dat die vroegtydige regsbeskerming van 'n spesie minder beswarend op individue en die staat sal wees, as regsbeskerming wat eers ingetree het op ' $\mathrm{n}$ stadium toe die betrokke spesie reeds deur uitwissing bedreig is. Hierdie insig het toepassingswaarde ten opsigte van die aanwending van omgewingsreg en -beleid vir die beskerming van roofvoëls in ander regstelsels, insluitend dié van Suid-Afrika.

* Assistance by the following institutions and persons is gratefully acknowledged: Financial assistance by the National Research Foundation of South Africa; assistance with the locating of source materials by Mr P Leadbeter and Dr A Wawryk of the Law School of the University of Adelaide and Mr P Jacobs and Mrs M Priwer of the Law Library of the University of Adelaide; and comments on a draft of this contribution, as well as assistance with access to further reference materials, by Dr S Debus of the University of New England and Prof P Olsen of the Australian National University. The views expressed here should not be attributed to the National Research Foundation or any other person or institution. 


\section{Introduction}

The Wedge-tailed Eagle is the largest Australian bird of prey, or raptor, species. "It has a wide distribution in Australia and is described as "common" or "locally common" in ornithological texts. ${ }^{2}$ Ferguson-Lees and Christie, who attempted to provide rough estimates of the population sizes of all the bird of prey species in the world, state that the population size of the Wedge-tailed Eagle is likely to be in the "hundreds of thousands", the highest figure given by the authors to any large eagle species. ${ }^{3}$ Ferguson-Lees and Christie are of the opinion that Wedge-tailed Eagle numbers may even be increasing in parts of Australia, ${ }^{4}$ and international conservation organisations also report the population trend as increasing. ${ }^{5}$ At a time when the general trend for large eagle species worldwide is to decline in numbers, and their conservation status gives cause for concern, the Wedge-tailed Eagle has fared better than most. ${ }^{6}$

The prima facie $^{7}$ sound conservation status of the Wedge-tailed Eagle is remarkable in view thereof that the species was, in the not too distant past, reputedly the most severely persecuted eagle species in the world. ${ }^{8}$ Sheep farming is a major Australian industry, and the Wedge-tailed Eagle was traditionally regarded as a prolific lamb killer. There was a time when governments of Australian States paid bounties for the destruction of Wedge-tailed Eagles. In 1892, the government of Western Australia

1 Aquila audax. BirdLife International Species factsheet: Aquila audax (2014) www.birdlife.org/datazone/speciesfactsheet.php?id = 3538 (accessed 201408-15); Debus Birds of Prey of Australia (2012) 125-127; Del Hoyo, Elliot \& Sargatal (eds) Handbook of the Birds of the World (1994) 198; Ferguson-Lees $\&$ Christie Raptors of the World (2001) 746-748; Global Raptor Information Network Species account: Wedge-tailed Eagle Aquila audax (2014) www.globalraptors.org/grin/SpeciesResults.asp?specID $=8349 \quad$ (accessed 2014-08-15); Marchant \& Higgins (eds) Handbook of Australian, New Zealand \& Antarctic Birds (HANZAB) (1993) 164-168; Olsen Wedge-tailed Eagle (2005); IUCN Red List of Threatened Species Aquila audax (2014) http:// www.iucnredlist.org/details/22696064/0 (accessed 2014-08-15). The terms 'bird of prey' and 'raptor' are used as synonyms in this contribution; see Kemp 'What is a Raptor?' in Newton (ed) Birds of Prey (1990) 14-31.

2 Debus 126; Del Hoyo, Elliot \& Sargatal (eds) 198; Ferguson-Lees \& Christie 746; Olsen 19-20. Marchant \& Higgins (eds) 166 state that the perceived status of the species may be biased because of its conspicuousness.

3 Ferguson-Lees \& Christie 748. For comparison, the Golden Eagle Aquila chrysaetos, which is the eagle species with the widest distribution on earth, is estimated by Ferguson-Lees \& Christie (745-746) also to have a total population size in the range of $100000-1000000$, with a total of 250000 individuals regarded as a likely figure.

$4 \quad$ Idem 748

5 BirdLife International Species factsheet: Aquila audax (2014) www.birdlife.org; IUCN Red List of Threatened Species Aquila audax (2014) www.iucnredlist.org.

6 Katzner \& Tingay (eds) The Eagle Watchers (2010) 1.

7 See cautionary remarks in par 3 below.

8 Burton \& Boyer Vanishing Eagles (1987) 85; Brooker 'Persecution of the Wedge-tailed Eagle' in Newton (ed) Birds of Prey (1990) 196; Olsen 91. 
offered a reward of two shillings per eagle destroyed. ${ }^{9}$ The number of eagles for which bounties were paid out in two of the States, Queensland and Western Australia, ran to 120000 in the period 1958-1967. ${ }^{10}$ It was a common practice in rural Australia to hang eagle carcasses in rows on roadside fences, after the birds had been shot, trapped or poisoned. ${ }^{11}$

The persecution of the Wedge-tailed Eagle was also formalised in legislation. The position in Western Australia may serve as an example. ${ }^{12}$ On 7 February 1919 the Governor declared ${ }^{13}$ "Eagle Hawks" 14 to be vermin throughout the State under the Vermin Boards Act, 1909. In the same year, the Vermin Boards Act was replaced in parts of the State by the Vermin Act, 1918, ${ }^{15}$ and in 1925 the Vermin Act replaced the Vermin Boards Act throughout the State. ${ }^{16}$ The Vermin Act placed a duty on any occupier of a holding to report the presence of vermin on the holding, or signs or marks of such presence, to certain appointed officials. ${ }^{19}$ All owners and occupiers of holdings also had a duty to destroy vermin, at all times and at their own expense, to the satisfaction of the relevant Minister or a vermin board. ${ }^{18}$ Penalties for non-compliance were provided for,${ }^{19}$ and officials were given the power to enter the holdings to search for vermin ${ }^{20}$ and, on holdings of non-compliant owners and occupiers, to perform activities deemed necessary for the destruction of vermin. ${ }^{21}$ Vermin boards were authorised to pay bonuses for the destruction of vermin in certain instances. ${ }^{22}$

Fortunately attitudes towards the Wedge-tailed Eagle have changed. Scientific investigation has shown that the numbers of lambs actually killed by Wedge-tailed Eagles are typically low. ${ }^{23}$ The legal status of the Wedge-tailed Eagle was changed from vermin to a species protected by the law. ${ }^{24}$ Deliberate persecution did not cease completely, but

9 Olsen 90

10 Idem 91

11 Idem 92; Brooker 'Persecution of the Wedge-tailed Eagle' in Newton (ed) supra $\mathrm{n} 8$ at 196.

12 Cf Olsen 90

$13 G G$ 6/1919 dd 7-2-1919 162

14 'Eagle hawk' (also 'Eaglehawk' or 'Eagle-hawk') was a vernacular name of the Wedge-tailed Eagle at the time; Olsen 11.

15 Vermin Act, 1918 ss $2 \& 3$ read with the First Schedule.

16 Vermin Act Amendment Act, 1925 ss $2 \& 3$. The Amendment Act specifically made provision for the paying of bonuses for the destruction of 'Eagle-Hawks' in s 10.

17 Vermin Act, $1918 \mathrm{~s} 93$

18 Idem s 94.

19 Idem ss $93,94 \& 97$.

20 Idem s 95.

21 Idem s 98.

22 Idem $\mathrm{s} 107$

23 See e.g. Brooker \& Ridpath 'The diet of the Wedge-tailed Eagle, Aquila audax, in Western Australia' 1980 Australian Wildlife Research 433-452; Leopold \& Wolfe 'Food habits of nesting Wedge-tailed Eagles, Aquila audax, in South-Eastern Australia' 1970 CSIRO Wildlife Research 1-17; cf Debus 126; Olsen 85; Ferguson-Lees \& Christie 747-748.

24 Olsen 92 
continued at a level that is perceived to be less intense and more localised. $^{25}$

The aim of this contribution is to give an overview of the current legal provisions that are relevant to the conservation status of the Wedgetailed Eagle; to offer critical remarks on their contributory role in respect of the conservation of the Wedge-tailed Eagle; and to reflect on the applicability of insights that are gained in this way to the legal conservation of a species in general, with a particular emphasis on birds of prey. Some comparative remarks are made in respect of the status of the Spanish Imperial Eagle in Spanish and European law and policy. In addition, some thoughts are presented on possible implications for the application of environmental legislation to further the conservation of birds of prey in South Africa.

\section{Legislation Affecting the Conservation Status of the Wedge-tailed Eagle}

\section{General}

Australian laws that determine the legal conservation status of the Wedge-tailed Eagle may be grouped into laws providing for direct, species-based protection and laws that confer indirect protection on species by aiming at the protection of wider aspects of the environment. In this contribution, the main focus is on laws providing direct protection. The applicable laws may furthermore be categorised according to the tier of government from which they emanate. On this basis, a distinction must be made between federal or Commonwealth legislation, and legislation of the States and Territories. ${ }^{26}$ The Commonwealth and the States and Territories exercise concurrent legislative powers in respect of most environmental issues, including environmental protection, with the States and Territories traditionally taking the most active part in respect of this. ${ }^{27}$ In cases of inconsistency, Commonwealth laws will prevail over State and Territory laws, ${ }^{28}$ but in respect of environmental matters the current trend is for the Commonwealth and States and Territories to follow a cooperative approach. ${ }^{29}$

International environmental law also exercises an influence on the legal status of Australian species. ${ }^{30}$ Two international legal instruments

25 Debus 126; Olsen 85; cf Ferguson-Lees \& Christie 747-748.

26 See in general Bates Environmental Law in Australia (2013) 129 and further 155 and further.

27 See in general Bates 129-130 \& 155-171 on constitutional arrangements in Australia and their effect on Australian environmental law; Aumann, Mooney \& Olsen 'The legal status of birds of prey in Australia' in Meyburg \& Chancellor (eds) Raptors in the Modern World (1989) 591.

28 Commonwealth of Australia Constitution Act s 109, Bates 160-162.

29 Bates 163-171

30 See in general Bates 97-125. 
that are particularly relevant in respect of the Wedge-tailed Eagle are the Convention on Biological Diversity 31 and the Convention on International Trade in Endangered Species ("CITES"). ${ }^{32}$ To be binding in Australia, international treaties must be ratified by the Commonwealth Government and be given effect in domestic legislation. ${ }^{33}$ This contribution focuses on the legislation of the Australian Commonwealth and the States and Territories, and the international legal instruments will not be discussed in detail here. ${ }^{34}$

\section{Direct, Species-based Protection}

\section{Federal or Commonwealth Laws}

The most important Federal Act currently dealing with the protection and conservation of biodiversity is the Environment Protection and Biodiversity Conservation Act 1999 (Cth) ("EPBCA"). ${ }^{35}$ The EPBCA List of Threatened Fauna, published under this Act, lists the Tasmanian subspecies of the Wedge-tailed Eagle ${ }^{36}$ as Endangered with effect from 16 July $2000 .^{37}$ The EPBCA provides that a person may not take an action that has, will have or is likely to have a significant impact on a listed threatened species, ${ }^{38}$ which includes endangered taxa such as the Tasmanian subspecies of the Wedge-tailed Eagle. ${ }^{39}$ The civil penalty for non-compliance is 5000 penalty units for an individual and 50000 penalty units for a juristic person. ${ }^{40}$ An action that has or will have a significant impact on an endangered species is also a strict-liability ${ }^{41}$

31 See www.cbd.int (accessed 2014-08-20); cf Bates 428-429.

32 See www.cites.org (accessed 2014-08-20); see further Bates 511; Aumann, Mooney \& Olsen 'The legal status of birds of prey in Australia' in Meyburg \& Chancellor (eds) supra $n 27$ at 594-595.

33 Bates 101-102,122\& 135.

34 But see par 221 on the implementation of CITES by Commonwealth legislation

35 Cf Bates 171-182.

36 Aquila audax fleayi. For detailed information on the Tasmanian subspecies of the Wedge-tailed Eagle, see www.environment.gov.au/cgi-bin/sprat/ public/publicspecies.pl?taxon_id = 64435 (accessed 2014-08-21)

37 www.environment.gov.au/cgi-bin/sprat/public/publicthreatenedlist.pl?want ed $=$ fauna\#birds_endangered (accessed 2014-08-21).

38 EPBCA s 18(3). 'Action' is defined in s 523 and 'impact' in s $527 \mathrm{E}$.

39 Idem s 178

40 Idem s 18(3). A 'penalty unit' is the lowest single monetary punishment, or fine, that can be imposed for a transgression of a law. In a jurisdiction where a penalty unit system is in force, different Acts impose fines on offences in multiples of the basic penalty unit. A single Act, that is devoted to sentencing, defines the monetary value of the basic penalty unit, and monetary penalties in all the Acts can thus be amended simultaneously by changing only the sentencing Act; see Mann (ed) Australian Law Dictionary (2013) 540. The current value of a penalty unit under Australian Commonwealth law is AUD 180; Crimes Act 1914 (Cth) s 4AA(1). The States and Territories have their own sentencing Acts and therefore the value of a penalty unit is not uniform across Australian jurisdictions.

41 There is no need to prove fault but mistake of fact is a defence; see the schedule to the Criminal Code Act 1995 (Cth) s 6.1 read with s 9.2. 
criminal offence, and the maximum punishment is seven years imprisonment or 420 penalty units, or both. ${ }^{42}$ Furthermore, killing, injuring, taking, trading, keeping and moving an endangered species in Commonwealth areas are prohibited and also constitute strict-liability criminal offences. ${ }^{43}$ Within 90 days of a species being listed, the Minister must decide whether a Recovery Plan for the species is necessary, ${ }^{44}$ and if deemed necessary, such a Recovery Plan must come into force within three years. ${ }^{45}$ If it is decided to adopt a Recovery Plan, it must provide for research and management actions that are necessary to stop the decline and support the recovery of the species to maximise its chances to survive in the wild. ${ }^{46}$ A Recovery Plan has indeed been adopted and implemented for the Tasmanian Wedge-tailed Eagle. ${ }^{47}$

Apart from the Tasmanian subspecies, the Wedge-tailed Eagle is not a listed species in the EPBCA itself. However, in terms of the Environment Protection and Biodiversity Conservation Regulations 2000 (Cth), published under the EPBCA, it is a protected species ${ }^{48}$ in Commonwealth areas. ${ }^{49}$ Therefore, any action in a Commonwealth area that would result in the death or injury of a Wedge-tailed Eagle, or that would involve the taking, trading, keeping or moving of it, is prohibited. Non-compliance can attract a civil or criminal penalty of 50 penalty units. ${ }^{50}$ Criminal liability is strict. ${ }^{51}$ Furthermore, damaging or destroying a nest of a Wedge-tailed eagle is also prohibited, and again the penalty or a transgression is 50 penalty units. ${ }^{52}$ These prohibited actions may be authorised by permits.

42 EPBCA s 18A. The Act makes provision for a number of exceptions to these prohibitions; see s 19.

43 Idem ss 196-196E.

44 Idem s 269AA.

45 Idem s 273(1).

46 Idem s 207(1).

47 The Tasmanian Wedge-tailed Eagle had a Recovery Plan at the time when a decision of the Minister was required, but at the moment a Recovery Plan is required for the subspecies; www.environment.gov.au/cgi-bin/sprat/public/ publicspecies.pl?taxon_id=64435\#summary (accessed 2014-08-21). A recovery team that has been formed for the Tasmanian Wedge-tailed Eagle was reported to be ineffective due to a funding shortage; see Debus 'Eagle recovery team canned' 2009 Boobook 36.

48 Environment Protection and Biodiversity Conservation Regulations 2000 (Cth). The Dictionary of the Act defines 'protected species' as a 'native species that is: (a) not a listed species; and (b) mentioned in Schedule 12; and (c) in, or taken in, a Commonwealth area to which Part 9 applies'. Schedule $12 \mathrm{cl} 2$ (b) lists species in the class Aves (birds) as a protected species. Part 9 deals with the conservation of biodiversity in Commonwealth areas.

49 Environment Protection and Biodiversity Conservation Regulations 2000 (Cth) reg 9.02.

50 Idem reg 9.03(1).

51 Idem reg 9.03(2).

52 Idem reg 9.03(3). 
The EPBCA also implements CITES ${ }^{53}$ in Australia, making it an offence to export or import specimens of species listed by CITES without a permit. ${ }^{54}$ The Wedge-tailed Eagle is listed in Appendix II of CITES, ${ }^{55}$ and is therefore subject to these provisions of the EPBCA. ${ }^{56}$ These provisions are applicable to the entire Australian population of the Wedge-tailed Eagle, not just the Tasmanian subspecies or birds in Commonwealth areas. $^{57}$

\section{Legislation of the States and Territories}

\section{Australian Capital Territory}

In terms of the Nature Conservation Act 2014 (ACT), ${ }^{58}$ a person may not, without a licence, kill, ${ }^{59}$ injure or place in danger of injury or death, 60 take, ${ }^{61}$ keep, ${ }^{62}$ sell, ${ }^{63}$ or import or export ${ }^{64}$ a Wedge-tailed Eagle. The maximum penalty for the most serious of these transgressions is 100 penalty units, one year imprisonment, or both. ${ }^{65}$ Interference with a nest is also prohibited, ${ }^{66}$ and such interference that endangers the lives of the eagles or their progeny, or places the eagles in danger of not breeding successfully, may attract a penalty of 100 penalty units, imprisonment for one year, or both. ${ }^{67}$ For less serious instances of nest interference, the penalty is 20 penalty units. ${ }^{68}$ "Nest" is defined to include a place, structure or object that has been used as a nesting place within the two

53 Par 21 supra.

54 EPBCA ss 303CC \& 303CD.

55 See http://cites.org/sites/default/files/eng/app/2014/E-Appendices-2014-0624.pdf (accessed 2014-08-21). Appendix II lists all species of the Falconiformes, with a few exceptions such as the species listed in the other appendices.

56 EPBCA S 303CA provides that the Minister must publish a list of CITES species, and the list must include all the species listed in appendices I, II and III of CITES.

57 EPBCA sS 303BA \& 303BC. These provisions regulate trade between Australia and other countries; cf Bates 512.

58 Cf Bates 527-528 on the Nature Conservation Act 1980 (ACT), which was the predecessor of the current Act.

59 Nature Conservation Act (ACT) S 130(1) read with the definition of 'native animal' in $\mathrm{s} 12$.

60 Idem s 133

61 Idem s 132 read with the definitions of 'native animal' in s 12 and 'take' in s 126.

62 Idem s 133 read with the definitions of 'native animal' in s 12 and 'exempt animal' in s 154 .

63 Idem s 134 read with the definitions of 'native animal' in s 12 and 'exempt animal' in s 154 .

64 Idem ss $136 \& 137$ read with the definition of 'exempt animal' in s 154

65 Idem ss 130-137; in respect of native animals with a special protection status under s 109 , the maximum penalty can be higher, but the Wedgetailed Eagle does not have such a special protection status.

66 Idem s 128(1) read with the definitions of 'native animal' in s 12, 'interfere with' and 'nest' in s 127.

67 Idem s 129(1) read with the definitions of 'native animal' in s 12, 'interfere with' and 'nest' in s 127 .

68 Idem s 128(1). 
previous years, as well as a partially constructed nest that has not been used as a nesting place. ${ }^{69}$

\section{New South Wales}

Under the National Parks and Wildlife Act 1974 (NSW), ${ }^{70}$ a person may not harm a Wedge-tailed Eagle. ${ }^{71}$ The definition of "harm" includes to hunt, shoot, poison, net, snare, pursue, capture, trap, injure or kill. ${ }^{72}$ The maximum penalty for such a transgression is 100 penalty units, plus an additional ten penalty units for each individual specimen harmed, or six months imprisonment. ${ }^{73}$ Buying, selling or possessing a Wedge-tailed Eagle without a licence is also prohibited, ${ }^{74}$ and a Wedge-tailed Eagle may also not be imported or exported from New South Wales. ${ }^{75}$

\section{Northern Territory}

Under the Territory Parks and Wildlife Conservation Act 1976 (NT), ${ }^{76}$ a person may not take or interfere with a Wedge-tailed Eagle, unless the person is authorised to do so under the Act. ${ }^{97}$ "Take" means to hunt, catch, restrain or kill, or to attempt to perform these actions or to assist with them. ${ }^{78}$ "Interfere with" means to harm, disturb, alter the behaviour, affect the capacity of the animal (here the eagle) to perform its natural processes, or to damage or destroy its habitat. ${ }^{79}$ Having a Wedge-tailed Eagle in possession or under control, ${ }^{80}$ as well as bringing a Wedge-tailed Eagle into, or taking it out of the Northern Territory, or releasing it in the Territory, is prohibited. ${ }^{81}$ The maximum penalty for these transgressions is 500 penalty units or five years imprisonment, or, if the offender is a juristic person, 2500 penalty units. ${ }^{82}$

\section{Queensland}

Under the Nature Conservation Act 1992 (Qld) ${ }^{83}$ and the Nature Conservation (Wildlife) Regulation 2006 (Qld), a person may not take,

69 Idem s 127

70 Cf Bates 528-530

71 National Parks and Wildlife Act (NSW) s 98(2) read with the definition of 'protected fauna' in s 5 and the list of 'unprotected fauna' in sch 11.

72 Idem s 5

73 Idem s 98(2)

74 Idem s 101 read with the definition of 'protected fauna' in s 5 and the list of 'unprotected fauna' in sch 11 .

75 Idem s 106 read with the definition of 'protected fauna' in s 5 and the list of 'unprotected fauna' in sch 11.

76 Cf Bates 531

77 National Parks and Wildlife Act (NSW) s 66(1) read with s 43, in which 'protected wildlife' is defined.

78 Idem $\mathrm{s} 9$

79 Ibid.

80 Idem s 66(2) read with s 43

81 Idem s 66(3) read with s 43.

82 Idem s 66.

83 Cf Bates 531-534. 
keep or use a Wedge-tailed Eagle without authorisation. ${ }^{84}$ "Take" includes to hunt, shoot, wound, kill, skin, poison, snare, trap, catch, pursue, lure, injure or harm; or to attempt to perform these activities. ${ }^{85}$ "Use" includes to buy, sell, give away, process, move or gain any benefit from the wildlife (in this instance the eagle). ${ }^{86}$ "Protected wildlife", including the Wedge-tailed Eagle, is to be managed to conserve the wildlife and its values, inter alia to ensure its survival and natural development; to identify, and reduce or remove processes threatening it; and to identify its critical habitat ${ }^{87}$ and conserve it to the greatest extent possible. ${ }^{88}$ Furthermore, management of protected wildlife must ensure that any use of the wildlife for scientific study and monitoring; for educational, recreational, commercial and other authorised purposes; or by Aboriginal people under their tradition, is ecologically sustainable. ${ }^{89}$ In principle, and subject to certain exceptions, Wedge-tailed Eagles are the property of the State. ${ }^{90}$

\section{South Australia}

Under the National Parks and Wildlife Act 1972 (SA), ${ }^{91}$ a person may not take a Wedge-tailed Eagle or its eggs without a permit. ${ }^{92}$ "Take" is defined to include any act of hunting, catching, restraining, killing or injuring, or any attempt to perform these activities. ${ }^{93}$ The National Parks and Wildlife Act also contains restrictions on releasing; ${ }^{94}$ keeping and selling; ${ }^{95}$ exporting and importing; ${ }^{96}$ and possessing or controlling Wedge-tailed Eagles. ${ }^{97}$ The Minister may declare open seasons for the

84 Nature Conservation Act (Qld) s 88 read with ss $71 \& 80$ of the Act, the definition of 'protected animal' in the Dictionary of the Act, and ss $35(2) \&$ $31 \&$ sch 6 of the regulations. In terms of these provisions, the Wedge-tailed Eagle belongs to the class 'least concern wildlife', which in turn is a component of 'protected wildlife'. S 33 of the regulations recognises that 'least concern wildlife' is a component of the biodiversity of Queensland and a vital feature of the ecosystem in which the wildlife lives. It also recognizes that such wildlife has inherent value and potential importance for the maintenance of ecosystem processes, and is a source of genetic information integral to understanding the evolution of Australian biota, and a genetic resource of potential benefit to society.

85 Dictionary of the Act.

86 Ibid.

87 'Critical habitat' is defined in s 13 of the Nature Conservation Act (Qld).

88 Nature Conservation Act (Qld) s 73(a).

89 Idem s 73(b)

90 Idem s 83.

91 Cf Bates 534-536.

92 National Parks and Wildlife Act (SA) s 51 read with s 53 and the definition of 'protected animal' in s 5 .

93 Idem s 5.

94 Idem s 55 read with the definition of 'protected animal' in s 5 .

95 Idem s 58 read with the definition of 'protected animal' in s 5.

96 Idem s 59 read with the definition of 'protected animal' in s 5.

97 Idem s 60. 
taking of specific species of protected animals, which could conceivably include the Wedge-tailed Eagle. ${ }^{98}$

\section{Tasmania}

The Wedge-tailed Eagle is listed as Endangered by the Threatened Species Protection Act 1995 (Tas). ${ }^{99}$ A person may not take, keep, trade in or process any specimen of the listed taxa; or disturb such a specimen under certain specified conditions; or release such a specimen into the wild. ${ }^{100}$ "Take" includes to kill, injure, catch, damage, destroy and collect. ${ }^{101}$ The Threatened Species Protection Act also provides that a Recovery Plan may be drawn up for endangered species. ${ }^{102}$

\section{Victoria}

Under the Wildlife Act 1975 (Vic), ${ }^{103}$ a person may not hunt, take, or destroy a Wedge-tailed Eagle without a licence. ${ }^{104}$ "Hunt" includes to pursue, trail, stalk, search for or drive out. ${ }^{105}$ The Wildlife Act furthermore provides that a person may not buy, sell, acquire, receive, dispose of, keep, possess, control, breed, process, display, take samples from or experiment on a Wedge-tailed Eagle. ${ }^{106}$ There are also prohibitions on importing and exporting, ${ }^{107}$ marking, ${ }^{108}$ and releasing $^{109}$ a Wedge-tailed Eagle. Willful molesting, injuring, or disturbing a Wedge-tailed Eagle is also an offence, as is the willful separating of a Wedge-tailed Eagle from its young. ${ }^{110}$ If a protected wildlife species, including the Wedge-tailed Eagle, appears to the Minister to be causing injury or damage to inter alia property or another kind of animal, that species may be declared to be unprotected in a specified area and for a specified period of time. ${ }^{111}$

\section{Western Australia}

Under the Wildlife Conservation Act 1950 (WA), ${ }^{112}$ all fauna is wholly

98 Idem s 52. For comments on open seasons in the era pre-1989, see Aumann, Mooney \& Olsen 'The legal status of birds of prey in Australia' in Meyburg \& Chancellor (eds) supra n 27 at 592.

99 Threatened Species Protection Act (Tas) s $13 \&$ sch 3.

100 Idem s 51 read with the definition of 'take' in s 3.

101 Idem s 3.

102 Idem s 25. This has been done for the Tasmanian Wedge-tailed Eagle, see par 221 supra.

103 Cf Bates 536-537.

104 Wildlife Act (Vic) s 43 read with the definition of 'protected wildlife' in s 3(1).

105 Idem s 3(1).

106 Idem s 47 read with the definition of 'protected wildlife' in s 3(1).

107 Idem s 50.

108 Idem s 51

109 Idem s 52

110 Idem s 58 read with the definition of 'protected wildlife' in s 3(1).

111 Idem s 7A.

112 Cf Bates 538-539. 
protected throughout the State. ${ }^{113}$ A person may not take ${ }^{114}$ a Wedgetailed Eagle, and "take" includes to kill or capture by any means, and to disturb or molest, and to attempt to or assist with these activities. ${ }^{115}$ Activities such as possessing, ${ }^{116}$ breeding, importing and exporting, selling or releasing a Wedge-tailed Eagle are also prohibited. ${ }^{117}$ The Minister may declare open seasons for fauna for specified periods in parts of, or throughout the State, ${ }^{118}$ and this discretion has on occasion been exercised in respect of the Wedge-tailed Eagle. ${ }^{119}$

\section{Indirect Protection}

Australia has a vast body of environmental legislation aimed at securing a healthy environment and sustainable development. ${ }^{120}$ Many of these laws should benefit the Wedge-tailed Eagle indirectly and, in the long run, may be more important for the conservation of biodiversity, including the Wedge-tailed Eagle, than legislation giving direct protection to wildlife species. ${ }^{121}$ However, this study concerns itself only with legislation impacting directly on the conservation status of the species, and for this reason environmental legislation of more general application, as important as it undeniably is, falls mainly outside the scope of this contribution.

Nevertheless, brief mention should be made here of legislation providing for the creation of protected areas such as national parks. ${ }^{122}$ The most important Commonwealth legislation in this regard is the EPBCA referred to above. ${ }^{123}$ The most important State and Territory laws in this regard are the Planning and Development Act 2007 (ACT); ${ }^{124}$ National Parks and Wildlife Act 1974 and Wilderness Act 1987 (NSW); ${ }^{125}$ Territory Parks and Wildlife Conservation Act 1976 (NT); ${ }^{126}$ Nature Conservation Act 1992 (Qld); ${ }^{127}$ National Parks and Wildlife Act 1972 (SA); ${ }^{128}$ Nature Conservation Act 2002 and National Parks and Reserves

113 Wildlife Conservation Act (WA) s 14.

114 Idem s 16.

115 Idem s 6.

116 Idem s 16A.

117 Idem s 17.

118 Idem s 14(2)

119 The Department of Conservation and Land Management issues so-called damages licences, but this is done cautiously and sparingly, in cases where damage is evident (Olsen personal communication 2014-04-02). For an older reference, see Aumann, Mooney \& Olsen 'The legal status of birds of prey in Australia' in Meyburg \& Chancellor (eds) supra n 27 at 592.

120 Bates 559.

121 Ibid.

122 See Bates 435-470.

123 Part 15; for commentaries cf Bates 438-453.

124 Ss 315-317; cf Bates 455.

125 Cf Bates 455-456.

126 Idem 458.

127 Idem 456-458.

128 Idem 459. 
Management Act 2002 (Tas); ${ }^{129}$ National Parks Act 1975 (Vic); ${ }^{130}$ and Land Administration Act 1997 and Conservation and Land Management Act 1984 (WA). ${ }^{131}$ Formally protected areas can be of great importance for the conservation of birds of prey, provided that such areas are large enough, and provided that the creation of such areas is supplemented by legal provisions that safeguard birds of prey when they venture outside such areas. ${ }^{132}$ A total of 17,88 percent of the land area of Australia has been set aside as protected terrestrial areas, and several of the individual protected areas are large enough to support significant Wedge-tailed Eagle populations. ${ }^{133}$

Another interesting and relevant aspect of Australian environmental law that potentially benefits the Wedge-tailed Eagle is the legal protection given to indigenous vegetation. Relevant legislation includes the Native Vegetation Act 2003 (NSW); ${ }^{134}$ Vegetation Management Act 1999 (Qld); ${ }^{135}$ Native Vegetation Act 1991 (SA); 136 and the Environmental Protection Act 1986 (WA). ${ }^{137}$ These and other legal provisions place various controls on the clearing of indigenous vegetation. ${ }^{138}$ In addition to legal controls on the clearing of indigenous vegetation, nongovernmental conservation organisations are involved in programmes for the active reintroduction of such vegetation. ${ }^{139}$ Interestingly, a view has been expressed that some clearing of native vegetation may have been beneficial to the Wedge-tailed Eagle. ${ }^{140}$ In the shorter term, clearing of vegetation may make it easier for the eagle to hunt, while leaving enough large trees intact to accommodate nests and to provide perches. However, in the longer term, if there is little recruitment of trees, the Wedge-tailed Eagle will be deprived of nesting opportunities and perches where it can rest and roost in safety. For this reason, the Wedge-tailed Eagle will probably ultimately benefit from legal provisions combating wholesale clearing of indigenous vegetation.

129 Idem 459-460

130 Idem 460-461.

131 Idem 461

132 Debus 146. Cf, in general, Department of the Environment State of the Environment 2011 (2011) www.environment.gov.au/topics/science-andresearch/state-environment-reporting/soe-2011 (accessed 2014-08-21) ch 8 par $441 \&$ Bates 431 . The provisions discussed in par 22 supra are examples of Australian legal provisions that safeguard birds of prey outside protected areas.

133 Collaborative Australian Protected Area Database (CAPAD) (2014) http:// www.environment.gov.au/land/nrs/science/capad/2014 (accessed 2015-1112); cf Bates 437.

134 Cf Bates 476-479

135 Idem 484-487.

136 Idem 480-484

137 Environmental Protection Act (WA) Ss 51 A-51 T; cf Bates 489-490.

138 See Bates 471-510.

139 Department of the Environment State of the Environment 2011 supra $\mathrm{n} 132$ at ch 8 par 44 2; cf Paton \& O'Connor The State of Australia's Birds 2009: Restoring Woodland Habitats for Birds (2010) birdlife.org.au/documents/ SOAB-2009.pdf (accessed 2013-11-09).

140 Debus 126; Ferguson-Lees \& Christie 748 


\section{Discussion}

In a conservation statement issued by Birds Australia, the forerunner of BirdLife Australia, Olsen has no trouble in finding a causal link between the adoption of protective laws and a recovery of Wedge-tailed Eagle populations, but she also hints at the resilience of the species. ${ }^{141}$ In her monograph on the species, Olsen finds a link between legal protection of the Wedge-tailed Eagle and changed attitudes among the human inhabitants of the country, but in the same breath she mentions the positive impact of the conservation movement and wildlife documentary films. ${ }^{142}$ Brooker also gives credit to the legal protection and the resilience of the species, but, in addition, credits prey availability and the sparse occupation of the countryside by humans as further reasons for the survival of the species. ${ }^{143}$ Burton and Boyer credit the last-mentioned factor with decisive importance. ${ }^{144}$

From the opinions of these authors, the following possible causal factors in the survival of the Wedge-tailed Eagle may be identified: Legal protection, an inherent resilience of the species, changed attitudes of the human population, the conservation movement, wildlife documentaries, prey availability, and low density of the human population. It is probably reasonable to conclude that all these factors have played a role, and to allow for the possibility that several others may also have contributed. Research, in this instance particularly into the true impact of eagle predation on livestock, comes to mind in this regard. ${ }^{145}$ Other factors that may have contributed are education of the public about the hunting behaviour and role of birds of prey in nature, ${ }^{146}$ and the fact that most Australian people now live in cities where they have little need for or interest in the killing of eagles. ${ }^{147}$

The above-mentioned positive views on the conservation status of the Wedge-tailed Eagle must be balanced with negative trends that are also apparent. Debus points out that the reporting rate of the Wedge-tailed Eagle in bird atlas projects has declined by 28 percent nationally and by 15 percent in New South Wales over the two decades to 2000, and that

141 Olsen Birds Australia Conservation Statement No 2 - Australia's Raptors: Diurnal Birds of Prey and Owls (1989) www.birdlife.org.au/documents/ OTHPUB-Raptors.pdf (accessed 2013-11-09) viii.

142 Olsen supra $n 1$ at 92.

143 Brooker 'Persecution of the Wedge-tailed Eagle' in Newton (ed) supra $\mathrm{n} 8$ at 196.

144 Burton \& Boyer 85.

145 See Olsen supra $n 1$ at 84-85; Debus 126 145; cf Ferguson-Lees \& Christie 747-748.

146 Cf Debus 149; Olsen Australian Birds of Prey (1995) 230-232.

147 Olsen personal communication 2014-04-02. 
numbers of the species have declined in the South of Australia due to habitat loss and disturbance. ${ }^{148}$ At a recent raptor conference held in Adelaide, ${ }^{149}$ a District Manager of the Department of Environment, Water and Natural Resources of South Australia reported that active persecution of the Wedge-tailed Eagle is still a regional reality, citing an extreme example where more than 100 Wedge-tailed Eagles were killed on a single farm in South Australia. ${ }^{150}$ It is perhaps realistic to conclude that while certain negative population trends may be apparent on national and regional levels, and whereas complacency would be inappropriate, the conservation status of the Wedge-tailed Eagle can be described as favourable compared to that of many other large eagle species of the world. Thus Debus mentions various negative impacts on Wedge-tailed Eagle populations, but nevertheless states that the species "remains widespread and common on the Australian mainland despite former intense persecution". ${ }^{151} \mathrm{He}$ also points out that whereas the Tasmanian subspecies is still officially classified as endangered, its position was reassessed more favourably, as vulnerable, in $2011 .^{152}$

Focusing specifically on the role of biodiversity legislation, and working with probabilities rather than hard facts, it appears safe to conclude that the law has played, and is still playing, an important contributory part in the conservation of the Wedge-tailed Eagle. Crucially, the law has changed its position from encouraging the destruction of Wedge-tailed Eagles by a bounty system, to outlawing the practice of killing Wedge-tailed Eagles and visiting it with penalties. While few judicial officers appear to enforce adequate penalties for the destruction of eagles, the small numbers of farmers and other individuals who still kill eagles, mostly do so surreptitiously and probably with

148 Debus 126; with reference to Barrett et al The New Atlas of Australian Birds (2003) 751. Note that Barrett et al caution (736) that atlas data is not well suited to making inferences about changes over time, and that comparisons of differing reporting rates in the two atlas periods should be interpreted with caution due to methodological changes and other factors.

149 Australasian Raptor Conference 2013 Adelaide (2013-08-10) 11.

150 The abstract of the paper has been published as Falkenberg 'Has the pendulum of public sentiment swung in favour of eagles? A regional perspective' 2013 Boobook 75. For a similar account from Tasmania, of a farmer claiming to have killed 230 eagles in an 18-month period, see Mooney 'Persecution of Wedge-tailed Eagles in Tasmania' 2011 Boobook 8. See further Aumann, Mooney \& Olsen 'The legal status of birds of prey in Australia' in Meyburg \& Chancellor (eds) supra n 27 at 593-594.

151 Debus 126. Cf par 1 supra. For an assessment of the outlook for Australian biodiversity in general, featuring both a pessimistic scenario and an optimistic one, see Department of the Environment State of the Environment 2011 supra $\mathrm{n} 132$ at ch 8 par 7.

152 By Birds Australia, forerunner of BirdLife Australia; see Garnett, Szabo \& Dutson The Action Plan for Austratian Birds 2010 (2011) 148-149. This change in status of the subspecies reflects a scientific assessment of its factual status. It legal status is unchanged, and it remains listed as endangered under the EPBCA (Cth) and the Threatened Species Protection Act 1995 (Tas); see Department of the Environment EPBCA list of threatened fauna (2009) http://www.environment.gov.au/cgi-bin/sprat/public/public threatenedlist.pl\#birds_extinct (accessed 2014-08-20). 
knowledge that such conduct is unlawful and is frowned upon by sectors of the community. ${ }^{153}$ It is reasonable to conclude that the relevant laws were instrumental, together with activities of researchers, conservation activists, producers of wildlife documentaries and so forth, to mitigate deep-seated prejudice, and, in its place, to foster a culture of respect and appreciation for wildlife in general and eagles in particular, ${ }^{154}$ although such a change of attitude has not permeated to all members of the community.

Interesting insights may be gained by comparing the legal protection of the Wedge-tailed Eagle in Australia with the legal protection of other eagle species in other jurisdictions. Only one example, and a remarkable one at that, will be considered here: The application of the environmental laws and policy of the European Union and Spain to save the Spanish Imperial Eagle from extinction. ${ }^{155}$ The European and Spanish conservation efforts in respect of the Spanish Imperial Eagle and the Australian conservation efforts in respect of the Wedge-tailed Eagle may both be regarded as prima facie successful. However, the interventions on behalf of the Spanish Imperial Eagle are much more numerous and intensive than those on behalf of the Wedge-tailed Eagle. Examples of such more numerous and intensive interventions include the creation of Special Protection Areas to enable the Spanish Imperial Eagle to breed and hunt in safety and without disturbance even on privately owned land; extensive research into juvenile dispersal patterns; the creation of dog and other patrols to combat the illegal use of poisons; and the adoption of management or Recovery Plans that are immensely detailed, ambitious and holistic in approach, to the point of providing for the management of prey animals, creating no-access zones around active nests (even by closing roads and restricting maintenance activities on power lines if needed), prohibiting the cutting down of trees containing nests that have been active in the previous ten years, structurally reinforcing nests in danger of collapsing, and implementing captive breeding programs to bolster wild breeding populations. A vast body of laws and environmental policy make the majority of these interventions mandatory. ${ }^{156}$ The interventions require a big financial commitment from governments and may be burdensome to persons such as landowners, who have breeding eagles on their properties and to juristic persons, such as electricity providers whose transmission structures may harbour occupied eagle nests or may pass through occupied eagle territories. $^{157}$

153 Olsen personal communication 2014-04-02.

154 E.g. the Wedge-tailed Eagle was chosen as the emblem of the Northern Territory in 1975; see Olsen supra n 1 at 92.

155 See Knobel 'The legal status of the Spanish Imperial Eagle in Spain and thoughts on environmental law and policy as contributing factors in the conservation of species' 2014 PER/PELJ 1828-1905.

156 Idem 1839-1866 for an overview of relevant legal provisions and policies at the levels of the European Union, the Spanish national government, and the Autonomous Communities of Spain.

157 Idem 1839-1866, $1874 \& 1876$ 
On the Australian mainland, by contrast, legal and other conservation interventions on behalf of the Wedge-tailed Eagle are not so numerous, far-reaching or intensive. ${ }^{158}$ Basic law enforcement appears to be more or less restricted to licencing controls and prosecution for offences, and these activities may be subject to relatively low funding levels and must often take place in the context of vast, thinly populated land surfaces. ${ }^{159}$ Some important interventions are not driven directly by the law. Examples include localised initiatives such as the involvement of local farming communities in bird of prey conservation goals, ${ }^{160}$ and an ambitious project to mitigate the effects of the clearing of Australian woodlands by re-vegetating land and creating corridors of indigenous vegetation linking remnant patches of woodland. ${ }^{161}$

In Tasmania, the local subspecies of the Wedge-tailed Eagle has been, due to its listing as endangered under the EPBCA, the object of more intensive measures, which are more comparable to the interventions on behalf of the Spanish Imperial Eagle. ${ }^{162}$ Examples include intensive searches, including by helicopter, to find and monitor nests, as well as the adaptation of forestry management practices to promote the breeding success of the eagles. ${ }^{163}$ In State forests, forestry operations are excluded from buffer zones around nests during the breeding season. ${ }^{164}$ Conservation officials investigate the complaints of farmers that eagles are preying on livestock, and, where possible, devise responses tailored to protect the interests of both the farmers and the eagles. An example is the issuing of licences which permit farmers to repeatedly discharge firearms near eagles in order to scare them away from livestock. ${ }^{165}$

158 See on the conservation of Australian raptors in general, Debus 152. In 1995, Olsen supra n 146 at 228 stated that conservation of Australian birds of prey had been largely confined to giving legal protection to all birds of prey and setting apart protected land. See Aumann, Mooney \& Olsen 'The legal status of birds of prey in Australia' in Meyburg \& Chancellor (eds) supra $\mathrm{n} 27$ at 595-596 for recommended improvements to Australian raptor legislation that were proposed in 1989.

159 Cf Aumann, Mooney \& Olsen 'The legal status of birds of prey in Australia' in Meyburg \& Chancellor (eds) supra $\mathrm{n} 27$ at 592-594.

160 E.g. Falkenberg supra n 150 at 75 supplies details of a Conservation Action Process that involves communities in a collaborative and transparent manner at a landscape level in South Australia.

161 Paton \& O'Connor supra $\mathrm{n} 139$ at 2; although this project is not earmarked specifically for the protection of the Wedge-tailed Eagle, the species may benefit from it.

162 Par 221 supra.

163 Koch, Wiersma \& Munks Tasmanian Wedge-tailed Eagle Nest Monitoring Project 2007-2012 (2013) www.fpa.tas.gov.au/ data/assets/pdf file/0004/ 87673/FPA_s_wedgetailed_eagle_nest_monitoring_project_2007-12_-_fin al.pdf (accessed 201 4-08-18); Mooney 'Tasmanian area rep's report 20052008' 2009 Boobook 8.

164 Debus 126-127; Olsen supran 1 at 93.

165 Mooney 'Wedge-tailed Eagles preying on sheep with "ryegrass staggers"' 2012 Boobook 17-18. It is worth noting that Mooney (18) also commends a member of the farming community for his patience and cooperation with such procedures. 
Conservationists also engage with the wind energy industry regarding eagle mortalities at wind energy turbines. ${ }^{166}$

The Spanish Imperial Eagle is classed as endangered by the International Union for Conservation of Nature ("IUCN"), while the Wedge-tailed Eagle is classed as a species of least concern. ${ }^{167}$ This difference in conservation status must in turn be linked to the small population size of the Spanish Imperial Eagle and its relatively small distribution range, compared to the large population size of the Wedgetailed Eagle and its vast distribution range. Expressed in terms of the history of decline of a population, one can characterise the most important legal interventions on behalf of the Spanish Imperial Eagle as relatively "late", whereas the important legal interventions on behalf of the mainland population of the Wedge-tailed Eagle may, in spite of having been preceded by nearly a century of intense persecution, be characterised as comparatively "early".

The Spanish conservation efforts in respect of the Spanish Imperial Eagle make an inspiring conservation success story, and are worthy of emulation by any jurisdiction with raptor populations in trouble. However, it is submitted that if a choice could still be made, it would be preferable to introduce full legal protection earlier in the history of the decline of a raptor species, as has been done for the Wedge-tailed Eagle. Such an earlier intervention is likely to be less costly to governments, less management-intensive, and less burdensome on landowners and other citizens than a later intervention. Ultimately, the potential for legal protection to ensure a secure future for its target species, is also likely to be better in the case of an early intervention compared to a later intervention.

This insight is of importance for the application of environmental law and policy to the conservation of birds of prey in other jurisdictions, including South Africa. Many of the South African bird of prey species still occur in relatively large populations, and relatively few species have been listed as endangered or critically endangered like the Spanish Imperial Eagle. However, an updated Red Data Book of Birds of South Africa, Lesotho and Swaziland will in the near future reflect the deteriorating

166 Cf e.g. Duchamp 'Windfarms: suspicious error by consultant condemns Tasmanian Eagle to extinction' 2012 Boobook 7-9 (see also commentary by the editor (9)); Hull $\&$ Sims 'Results from ten years of eagle studies at the Bluff point and Studland Bay wind farms, Tasmania' 2013 Boobook 47; Mooney 'Priority work required for Wedge-tailed Eagle conservation in Tasmania' 2013 Boobook 15; Mooney 'Projecting Wedge-tailed Eagle Aquila audax fleayii and White-bellied Sea-Eagle Haliaeetus leucogaster mortality from collisions with wind-farms in Tasmania' 2012 Boobook 54; Mooney 'Windfarms' 2013 Boobook 5-6; Smales 'Modelling wind farm collision risk for raptors' 2012 Boobook 42-44.

167 IUCN Red List of Threatened Species Aquila adalberti (2014) www.iucnredlist.org/details/22696042/0 (accessed 2014-08-20); IUCN Red List of Threatened Species Aquila audax (2014) www.iucnredlist.org/details/ 22696064/0 (accessed 2014-08-20). 
conservation status of several South African bird of prey species. ${ }^{168}$ Twelve South African bird of prey species are likely to be listed as endangered ${ }^{169}$ and two species as critically endangered. ${ }^{170}$ The prima facie effectiveness of the legal protection of the Wedge-tailed Eagle in Australia supports a strong case that many bird of prey species, and certainly larger species such as eagles and vultures, should be given full legal protection as early as possible. Focusing, for instance, on South African eagles, only four species enjoy full legal protection under national legislation. ${ }^{171}$ All bird of prey species are protected under provincial legislation, ${ }^{172}$ but the position is not entirely satisfactory. ${ }^{173}$ One major weakness in certain provincial laws is the immunity enjoyed by landowners and their families, including persons acting with their authority, for the killing of eagles and other birds of prey. In the relevant provinces, which constitute a large part of South Africa, the mentioned persons do not need to obtain permission from conservation authorities to kill eagles. ${ }^{174}$ Much of the Karoo, which is probably the most wellknown sheep-farming region in South Africa, and the mohair goat farming areas of the Eastern Cape, are situated inside these provinces where landowners enjoy immunity for the killing of eagles on their land.

168 Release of this publication is imminent; www.birdlife.org.za/publications/ red-data-book-of-birds (accessed 2014-08-15); see further Knobel supra $\mathrm{n}$ 155 at 1877.

169 They are the Hooded Vulture Necrosyrtes monachus; Cape Vulture Gyps coprotheres; White-backed Vulture Gyps africanus; Lappet-faced Vulture Torgos tracheliotos; White-headed Vulture Trigonoceps occipitalis; Black Harrier Circus maurus; African Marsh Harrier Circus ranivorus; Bateleur Terathopius ecaudatus; Southern Banded Snake Eagle Circaetus fasciolatus; Martial Eagle Polemaetus bellicosus; Tawny Eagle Aquila rapax and Pel's Fishing Owl Scotopelia peli.

170 Bearded Vulture Gypaetus barbatus and Taita Falcon Falco fasciinucha

171 They are the Bateleur Terathopius ecaudatus; Southern Banded Snake Eagle Circaetus fasciolatus; Martial Eagle Polemaetus bellicosus and Tawny Eagle Aquila rapax, all classified as 'vulnerable'; see National Environmental Management (Biodiversity) Act 10 of 2004 s 56, read with the Threatened or Protected Species Regulations (GN R152 in GG 29657 of 2007-02-23) and the Lists of Critically Endangered, Endangered, Vulnerable and Protected Species (GN R151 in GG 29657 of 2007-02-23); see Knobel 'The conservation status of eagles in South African law' 2013 PER/PELJ 183/487. A revised new Threatened or Protected Species list has been published for comment in March 2015: Publication of Lists of Species that are Threatened or Protected, Activities that are Prohibited and Exemption from Restriction (Gen N 256 in GG 38600 of 2015-03-31). This draft list classifies 3 raptor species as 'critically endangered' and 10 raptor species, including 3 eagle species (the Bateleur, Martial Eagle and Tawny Eagle) as 'endangered'. The Southern Banded Snake Eagle is not listed. If the draft list is enacted, the legal position of raptors will be better than the current one, but much room for improvement will remain. E.g. the new Red List will list 5 bird of prey species as 'vulnerable', while the draft Threatened or Protected Species list does not classify any raptor species as 'vulnerable'.

172 Knobel supra n 171 at 186/487-190/487.

173 Idem 198/487-204/487.

174 E.g. Nature and Environmental Conservation Ordinance 19 of 1974 s 27; see Knobel supra $\mathrm{n} 171$ at 190/487; the Ordinance is in force in both the Western and Eastern Cape provinces. 
Therefore, some of the regions with the highest potential for a perceived conflict ${ }^{175}$ between the conservation of eagles and the financial interests of the human occupants of the land, fall squarely in a part of South Africa where protection under provincial legislation is inadequate.

The Australian position, where the killing of eagles is outlawed in principle but provision is made that landowners may obtain permits for killing eagles in meritorious instances, ${ }^{176}$ is by far the preferable approach. To prevent a scenario where comparatively radical legal measures, like those pertaining to the Spanish Imperial Eagle, are eventually required to protect many South African bird of prey species, an Australian-style legal protection regime is highly desirable. This would require reform of provincial legislation in instances where the legal protection of raptors falls short, or, more preferably, bestowing a comprehensive protection status on eagles, vultures and other vulnerable bird of prey species under national legislation. ${ }^{177}$

175 The phrase 'perceived conflict' is used deliberately. While larger eagles are capable of killing small-stock lambs, and while some such predation undoubtedly takes place, its scope and impact are usually exaggerated. Furthermore, the presence of large eagles on a small-stock farm may in fact benefit the farmer financially, because the eagles prey on wild animals that compete with domestic stock for grazing; for an in-depth analysis see Davies 'The extent, cost and control of livestock predation by eagles with a case study on Black Eagles (Aquila verreauxii) in the Karoo' 1999 Journal of Raptor Research 67-72. Also, most eagles will take carrion, and for this reason, seeing an eagle feeding on a lamb does not in itself constitute proof that the eagle has killed the lamb; see Knobel supra n 171 at 163/487 n 14. 176 As discussed in par 22 supra.

177 Knobel supra n 171 at 198/487-204/487. 